\title{
Peran Ayah, Dukungan Teman Sebaya dan Ekspose Media Pornografi dengan Perilaku Seksual Berpacaran pada Remaja
}

\author{
Afrizawati $^{1}$, Nina zulida situmorang ${ }^{2}$. Purwadi ${ }^{3}$ \\ Fakultas Tarbiyah dan Keguruan, Program Studi Bimbingan Konseling, \\ Institut Agama Islam Abdullah Said Batam ${ }^{1}$ \\ Fakultas Psikologi Universitas Ahmad Dahlan²,3 \\ neysharizha@gmail.com ${ }^{1}$
}

\begin{abstract}
Abstrak
Penelitian ini bertujuan untuk mengetahui hubungan peran ayah, dukungan teman sebaya dan ekspose media pornografi dengan perilaku seksual berpacaran. Subjek penelitian ialah siswa-siswi SMA Muhammadiyah 2 Yogyakarta. Jumlah subjek sebanyak 168 siswa dengan rentang usia sekitar 17-19 tahun menggunakan teknik Cluster Random Sampling. Instrumen yang digunakan ialah skala perilaku seksual berpacaran, skala peran ayah, skala dukungan teman sebaya dan skala ekspose media pornografi. Hasil analisis menunjukkan: 1) Tidak ada hubungan peran ayah, dukungan teman sebaya dan ekspose media pornografi dengan perilaku seksual berpacaran, dengan taraf signifikan sebesar $0,062(\mathrm{p}>0.05)$. 2) Tidak ada hubungan peran ayah dengan perilaku seksual berpacaran, dengan nilai signifikan $0,708(p>0,05)$. 3) Ada hubungan dukungan teman sebaya dengan perilaku seksual berpacaran, dengan nilai signifikan $0,043(\mathrm{p}<0,05)$. 4) Ada hubungan ekspose media pornografi dengan perilaku seksual berpacaran, dengan nilai signifikan 0,041 ( $<<0,05)$. Penelitian ini menunjukkan peran ayah, dukungan teman sebaya dan ekspose media pornografi secara bersama-sama tidak ada hubungan dengan perilaku seksual berpacaran. Dari tiga variabel independen, variabel peran ayah tidak ada hubungan dengan perilaku seksual berpacaran. Sedangkan variabel dukungan teman sebaya dan variabel ekspose media pornografi merupakan variabel yang ada hubungannya dengan perilaku seksual berpacaran.
\end{abstract}

Kata Kunci : Peran Ayah, Dukungan Teman Sebaya, Ekspose Media Pornografi, Perilaku Seksual Berpacaran.

\begin{abstract}
This study aims to determine the relationship of the role of fathers, peer support and exposure to pornographic media with sexual behavior in dating adolescents. The subjects of the study were high school students of Muhammadiyah 2 Yogyakarta. The number of subjects was 168 students with an age range of around 17-19 years collected using the Cluster Random Sampling technique. The instruments used were the sexual behavior scale in dating, father's role scale, peer support scale, and porn media exposure scale. The analysis showed: 1) There was no relationship between the role of fathers, peer support and exposure to pornographic media with sexual behavior dating, with a significant level of 0.062 ( $p>0.05)$. 2) There was no relationship between the role of fathers with sexual behavior in dating, with a significant value of $0.708(p>0.05)$. 3) There was a relationship between peer support and sexual behavior in dating, with a significant value of $0.043(\mathrm{p}<0.05)$. 4) There was a relationship between exposure to pornographic media and sexual behavior in dating, with a significant value of $0.041(\mathrm{p}<0.05)$. This study shows the role of fathers, peer support, and exposure to pornography together have no relationship with sexual behavior in dating. Of the three independent variables, the father's role variable has no relationship with dating sexual behavior. While the peer support variable and pornographic media exposure variable are variables related to dating sexual behavior.
\end{abstract}

Keywords: Father's Role, Peer Support, Porn Media Exposure, Sexual Behavior in dating. 


\section{PENDAHULUAN}

Saat ini, di Indonesia perilaku seksual dalam status berpacaran telah mengalami peningkatan dan mengalami perubahan perilaku. Dahulu pacaran hanya meliputi perilaku jalan-jalan, berkunjung kerumah pacar maupun nonton bersama, namun saat ini pacaran mulai mendekati hubungan seks seperti ciuman, rabaan pada tubuh dan alat reproduksi sampai melakukan hubungan seks, dengan asumsi bukan pacaran jika tidak melakukan hubungan seks bebas (Aryani, 2017).

Sikap remaja terhadap perilaku seks bebas telah mengalami perubahan. Imaduddin (2012) perilaku berpacaran konvensional yang tanpa melakukan seks bebas akan menumbuhkan rasa malu serta bersalah bagi remaja, sementara saat ini hubungan seks sebelum nikah dianggap benar apabila dilakukan dengan rasa cinta. Bahkan pada penelitian Taufik (2013) mengungkapkan di kalangan pelajar Sekolah Menengah Kejuruan di Samarinda ada 14 $\%$ remaja yang mengaku berhubungan seks saat berpacaran dari total 400 responden.

Ada banyak faktor yang mempengaruhi perilaku seksual pada remaja, baik itu faktor internal maupun eksternal seperti rasa ingin tahu, motivasi karena adanya ajakan teman, orangtua dan lingkungan (Evi, Natsir, \& Suriah, 2013). Hasil penelitian Soetjiningsih (2008) menunjukkan bahwa faktor-faktor yang mempengaruhi perilaku seks pranikah remaja adalah hubungan orangtua remaja. Pola asuh orangtua menurut Santrock (2011) juga mempengaruhi perkembangan seksual remaja. Keterbukaan orang tua dalam berkomunikasi terkait dengan masalah seksual membuat anak-anak memiliki pengetahuan yang cukup dan tidak takut mengemukakan pendapat berkaitan dengan hal yang di anggap tabu. Lebih lanjut, menurut Brooks (2011) perilaku pengasuhan dan kesejahteraan anak tergantung pada kualitas hubungan orangtua. Hubungan yang baik antara ibu dan ayah juga akan menimbulkan pengasuhan yang baik, sehingga konflik akan diselesaikan dengan cara kompromi dan menunjukkan emosi yang positif.

Namun demikian penelitian Aryani (2017) secara khusus menyarankan pentingnya peran ayah dalam pengasuhan, ia menyatakan bahwa perilaku seksual ketika berpacaran pada remaja bisa dikendalikan dengan pola asuh ayah. Semakin baik pola asuh ayah, maka kecenderungan perilaku seksual berpacaran pada remaja semakin rendah

Penelitian yang dilakukan oleh Yeung dan Jean (2015) menemukan bahwa keterlibatan ayah dalam pengasuhan anak di enam negara asia (India, Shanghai, Malaysia, Vietnam, Jepang dan Filipina) masih rendah jika dibandingkan dengan negara-negara barat, dan pengasuhan serta dukungan emosional masih didominasi oleh ibu. Pada umumnya remaja cenderung tidak bebas membicarakan hal-hal seksual pada orang tua meraka, sehingga teman sebaya menjadi tempat yang tepat untuk berbagi perihal ini (Santrock, 2003). Teman sebaya dianggap lebih terbuka dan mudah dalam memberikan informasi yang mengandung unsur-unsur pengalaman seksual meskipun informasi tersebut dianggap kurang sehat dari sisi moral, mental maupun medis (Pramono, Dewi, \& Auliatunida, 2010). Informasi yang di dapat dari teman sebaya dapat memicu keinginan untuk mendapatkan pengalaman dalam perilaku seksual baik secara langsung maupun tidak, hal ini juga di sampaikan oleh Soetjiningsih (2008) bahwa tekanan negatif dari teman sebaya dapat menjadi faktor penyebab individu melakukan perilaku seksual.

Salah satu faktor lain yang mempengaruhi perilaku seksual pada remaja adalah pengaruh media, salah satunya ekspose media pornografi Soetjiningsih (2008). Ekspose media pornografi pada saat ini sangat marak. Maraknya peredaran media-media pornografi yang 
sangat mudah diakses, makin memudahkan remaja mengalami ekspose pornografi. Utari, Syarifah, dan Lubis (2012) mengungkapkan bahwa informasi yang disajikan secara terbuka oleh media elektronik maupun media dapan menjadi sumber referensi bagi remaja dalam memahami perilaku seksual, namun hal ini dapat berdampak negatif apabila informasi yang disampaikan di sajikan dengan cara yang tidak benar dan mengakibatkan remaja terjebak pada perilaku seks yang tidak sehat.

Faktor eksternal yang banyak mempengaruhi pengambilan keputusan perilaku seseorang adalah arus informasi yang kuat. Mengakses internet terutama jejaring sosial saat ini sudah menjadi rutinitas masyarakat terutama remaja. Remaja yang menggunakan jejaring sosial cenderung lebih beresiko terhadap perilaku seksual. Remaja masih berjiwa labil dan emosional sehingga sering salah menafsirkan informasi yang terdapat di jejaring sosial. Kebanyakan remaja menggunakan jejaring sosial untuk mencari pasangan dan akhirnya melakukan hubungan seksual tidak sehat (Pratama \& Setiyaningsih, 2015).

Pertumbuhan penggunaan internet di Indonesia meningkat pesat. Asosiasi penyelenggaraan jasa internet menyebutkan bahwa pada tahun 2009 mengguna internet di Indonesia mencapai $64 \%$ juta. Sedangkan riset yang dilakukan oleh Yahoo menunjukkan pengguna internet terbanyak di Indonesia adalah usia 15-19 tahun mencapai 64\%, dan usia tersebut termasuk kedalam golongan remaja (Pratama \& Setiyaningsih, 2015). Berdasarkan latar belakang tersebut, peneliti tertarik untuk menguji apakah ada hubungan peran ayah, dukungan teman sebaya dan ekspose media pornografi dengan perilaku seksual berpacaran

\section{METODE}

Subjek dalam penelitian ini berjumlah 168 siswa dikumpulkan dengan menggunakan teknik cluster random sampling. Skala yang digunakan adalah skala Perilaku Seksual Berpacaran, Peran Ayah, Dukungan Teman Sebaya dan Ekspose Media Pornografi. Skala Perilaku Seksual Berpacaran terdiri dari 38 aitem dengan $\alpha$ 0,947. Contoh aitem skala perilaku seksual berbacaran adalah "Saya mencium pipi pacar sebagai ungkapan perasaan sayang kepadanya". Skala Peran Ayah terdiri dari 27 aitem dengan $\alpha$ 0,889. Contoh aitem skala Peran Ayah adalah "Ayah merespon positif saat saya mengenalkan pacar saya kepada ayah dan keluarga". Skala Dukungan Teman Sebaya terdiri dari 29 aitem a 0,931. Contoh aitem skala Dukungan Teman Sebaya adalah "Teman-teman saya memberikan informasi apa yang saya butuhkan". Skala Ekspose Media Pornografi terdiri dari 15 aitem dengan $\alpha$ 0,892. Contoh aitem skala Ekspose Media Pornografi adalah "Bila saya melihat adegan-adegan porno dibioskop, TV, internet atau media lainnya, rasanya ingin melihat terus". Skala dibuat dengan memberikan empat alternatif jawaban yang dimodifikasi berdasarkan model skala Likert yaitu distribusi respon sebagai dasar penentuan nilai skalanya, penilaiannya didasarkan pada sangat tidak sesuai (STS), tidak sesuai (TS), sesuai (S) dan sangat sesuai (SS).

\section{HASIL}

Tabel 1.

Gambaran Hipotetik variabel

\begin{tabular}{cllcccccc}
\hline \multirow{2}{*}{ Variabel } & \multicolumn{4}{c}{ Empirik } & \multicolumn{4}{c}{ Hipotetik } \\
\cline { 2 - 10 } & Maks & Min & Mean & SD & Maks & Min & Mean & SD \\
\hline Perilaku Seksual Berpacaran & 30 & 62 & 44,53 & 6,33 & 17 & 68 & 42,5 & 8,5 \\
\hline 55
\end{tabular}




\begin{tabular}{ccccccccc}
\hline Peran Ayah & 30 & 63 & 49,72 & 5,19 & 18 & 72 & 45 & 9 \\
\hline Dukungan Teman Sebaya & 47 & 103 & 80,90 & 8,27 & 26 & 104 & 65 & 13 \\
\hline Ekspose Media Pornografi & 12 & 35 & 18,19 & 5,75 & 12 & 48 & 16 & 6 \\
\hline
\end{tabular}

Berdasarkan tabel 1 di atas dapat diketahui bahwa skor mean empirik variabel perilaku seksual berpacaran sebesar 44,53 lebih rendah dari skor mean hipotetiknya yaitu 42,5. Kemudian skor mean empirik variabel peran ayah sebesar 49,72 lebih tinggi dari skor mean hipotetiknya yaitu 45. Skor mean empirik variabel dukungan teman sebaya sebesar 80,90 lebih tinggi dari skor mean hipotetiknya yaitu 65. Skor mean empirik variabel ekspose media pornografi sebesar 18,19 lebih tinggi dari skor mean hipotetiknya yaitu 16 .

Tabel 2.

Kategori variabel Penelitian

\begin{tabular}{ccccccc}
\hline \multirow{2}{*}{ Variabel } & \multicolumn{2}{c}{ Tinggi } & \multicolumn{2}{c}{ Sedang } & \multicolumn{2}{c}{ Rendah } \\
\cline { 2 - 7 } & Frekuensi & $\%$ & Frekuensi & $\%$ & frekuensi & $\%$ \\
\hline Perilaku Seksual Berpacaran & 41 & $24,4 \%$ & 115 & $68,4 \%$ & 12 & $7,1 \%$ \\
\hline Peran Ayah & 90 & $53,5 \%$ & 72 & $42,8 \%$ & 6 & $3,5 \%$ \\
\hline Dukungan Teman Sebaya & 150 & $89,2 \%$ & 17 & $10,1 \%$ & 1 & $0,5 \%$ \\
\hline Ekspose Media Pornografi & 0 & $0 \%$ & 133 & $79,1 \%$ & 35 & $20,8 \%$ \\
\hline
\end{tabular}

Berdasarkan tabel 2 di atas, dapat diketahui bahwa subjek yang mengalami perilaku seksual berpacaran dalam kategori tinggi ialah sebanyak 41 orang $(24,40 \%)$, sedangkan subjek yang mengalami perilaku seksual berpacaran dalam kategori sedang ialah sebanyak 115 orang $(68,45 \%)$ dan subjek yang mengalami perilaku seksual berpacaran dalam kategori rendah ialah sebanyak 12 orang $(7,14 \%)$. Kemudian, subjek yang memiliki peran ayah dalam kategori tinggi ialah sebanyak 90 orang $(53,57 \%)$, sedangkan subjek yang memiliki peran ayah dalam kategori sedang ialah sebanyak 72 orang $(42,85 \%)$ dan subjek yang memiliki peran ayah dalam kategori rendah ialah sebanyak 6 orang $(3,57 \%)$.

Subjek yang memiliki dukungan teman sebaya dalam kategori tinggi ialah sebanyak 150 orang $(89,28 \%)$, sedangkan subjek yang memiliki dukungan teman sebaya dalam kategori sedang ialah sebanyak 17 orang $(10,12 \%)$ dan subjek yang memiliki dukungan teman sebaya dalam kategori rendah ialah sebanyak 1 orang $(0,59 \%)$. Melalui tabel 2 juga dapat diketahui bahwa subjek yang memiliki ekspose media pornografi dalam kategori tinggi ialah sebanyak 0 orang $(0 \%)$, sedangkan subjek yang memiliki ekspose media pornografi dalam kategori sedang ialah sebanyak 133 orang $(79,17 \%)$ dan subjek yang memiliki ekspose media pornografi dalam kategori rendah ialah sebanyak 35 orang $(20,83 \%)$.

\section{Uji Asumsi}

Uji normalitas menunjukkan nilai Kolmogorov Smirnov adalah 0,992 ( $\mathrm{p}>0,05)$ berarti data terdistribusi normal. Sedang uji linearitas pada penelitian ini dapat di lihat pada tabel 3, berikut ini :

Tabel 3.

Uji Linearitas

\begin{tabular}{cccc}
\hline Perilaku Seksual Berpacaran & $\boldsymbol{F}$ Linearity & Signifikansi & Keterangan \\
\hline Peran Ayah & 1,198 & 0,256 & Linear \\
\hline
\end{tabular}




\begin{tabular}{cccc}
\hline Dukungan Teman Sebaya & 1.306 & 0,149 & Linear \\
\hline Ekspose Media Pornografi & 0,676 & 0,857 & Linear \\
\hline
\end{tabular}

\section{Uji Hipotesa}

\section{Tabel 4.}

Uji Hipotesis

\begin{tabular}{lcccc}
\multicolumn{1}{c}{ Variabel } & Mean Square & F & Sig & Keterangan \\
\hline $\begin{array}{l}\text { Peran ayah, dukungan teman sebaya } \\
\text { dan Ekspose pornografi }\end{array}$ & 97,374 & 2,492 &, $062^{\mathrm{a}}$ & Signifikan \\
\hline & Beta & t hitung & Sig & Keterangan \\
\hline Peran Ayah & 0,029 & 0,375 & 0,708 & Tidak Signifikan \\
\hline Dukungan Teman Sebaya & 0,158 & 2,039 & 0,043 & Signifikan \\
\hline Ekspose Media Pornografi & 0,159 & 2,062 & 0,041 & Signifikan \\
\hline
\end{tabular}

Keterangan: dependen; perilaku seksual berpacaran

Hipotesis pertama berbunyi "ada hubungan peran ayah, dukungan teman sebaya dan ekspose media pornografi terhadap perilaku seksual berpacaran pada remaja di sekolah swasta Yogyakarta". Berdasarkan tabel 4. dapat dilihat bahwa koefien korelasi $F=2,492$ dengan taraf signifikan sebesar $\mathrm{p}=0,062(\mathrm{p}>0,05)$ yang berarti tidak signifikan, hipotesis ditolak. Jadi dapat disimpulkan bahwa tidak ada hubungan peran ayah, dukungan teman sebaya dan ekspose media pornografi dengan perilaku seksual berpacaran pada remaja di sekolah swasta Yogyakarta. Hipotesis kedua berbunyi "ada hubungan peran ayah dengan perilaku seksual berpacaran pada remaja di sekolah swasta Yogyakarta". Berdasarkan hasil analisis yang menguji hubungan peran ayah dengan perilaku seksual berpacaran diperoleh nilai correlation coefficient (koefisien korelasi) sebesar 0,035 dan nilai beta sebesar 0,029 dengan nilai signifikan 0,708 ( $\mathrm{p}>0,05)$ yang berarti tidak signifikan, hipotesis ditolak. Sehingga dapat disimpulkan tidak ada hubungan peran ayah dengan perilaku seksual berpacaran pada remaja di sekolah swasta Yogyakarta.

Penelitian ini menunjukkan bahwa Hipotesis ke 3 dan ke dua di terima. Hipotesis ketiga berbunyi "ada hubungan dukungan teman sebaya dengan perilaku seksual berpacaran pada remaja di sekolah swasta Yogyakarta". Berdasarkan hasil analisis yang menguji peran dukungan teman sebaya dengan perilaku seksual berpacaran diperoleh nilai correlation coefficient (koefisien korelasi) sebesar 0,121 dan nilai beta sebesar 0,158 dengan nilai signifikan $0,043 \quad(\mathrm{p}<0,05)$ yang berarti signifikan, hipotesis diterima. Sehingga dapat disimpulkan bahwa ada hubungan dukungan teman sebaya dengan perilaku seksual berpacaran pada remaja di sekolah swasta Yogyakarta. Hipotesis keempat berbunyi "ada hubungan ekspose media pornografi dengan perilaku seksual berpacaran pada remaja di sekolah swasta Yogyakarta”. Berdasarkan hasil analisis yang menguji ekspose media pornografi dengan perilaku seksual berpacaran diperoleh nilai correlation coefficient (koefisien korelasi) sebesar 0,175 dan nilai beta sebesar 0,159 dengan nilai signifikan $0,041 \quad(\mathrm{p}<0,05)$ yang berarti signifikan, hipotesis diterima. Sehingga dapat disimpulkan bahwa ada hubungan ekspose media pornografi dengan perilaku seksual berpacaran pada remaja di sekolah swasta Yogyakarta.

Melalui penelitian juga diperoleh nilai R square sebesar 0,044 dengan taraf signifikan 0,62. Variabel peran ayah, dukungan teman sebaya dan ekspose media pornografi secara bersamasama memberikan sumbangan efektif terhadap perilaku seksual berpacaran sebesar 4,4\%, 
sehingga apabila dianalisis, korelasi hubungan semua variabel secara bersama-sama tidak signifikan.

\section{PEMBAHASAN}

Dari pengujian hipotesis pertama diperoleh hasil bahwa peran ayah, dukungan teman sebaya dan ekspose media pornografi secara bersama-sama sebagai variabel bebas tidak berperan dengan perilaku seksual berpacaran pada remaja. Artinya tidak ada hubungan antara peran ayah, dukungan teman sebaya dan ekspose media pornografi secara bersama-sama dengan perilaku seksual berpacaran pada remaja di SMA Muhammadiyah 2 Yogyakarta. Hasil penelitian menunjukkan bahwa peran ayah tidak memiliki kontribusi pada perilaku seksual individu ketika berpacaran, namun dukungan teman sebaya dan ekspose media pornografi memiliki peranan dalam mempengaruhi individu untuk berperilaku seksual ketika berpacaran.

Menurut Green (2006), ada beberapa faktor yang dapat mempengaruhi individu dalam berperilaku meliputi faktor predisposisi, faktor pendukung, dan faktor pendorong. Peranan ayah di mungkinkan hanya sebatas predisposisi yang tidak dapat mempengaruhi secara langsung perilaku remaja. Ketiadaan peranan ayah terhadap perilaku seksual dalam berpacaran pada anak bertentangan dengan penelitian Soetjiningsih (2008), namun demikian hal ini dapat dipahami melalui apa yang disampaikan Santrock (2003) bahwa remaja cenderung lebih mendengarkan teman sebaya dibanding orang tua terkait masalah seksual. Hurlock (2003) mengungkapkan pada tahap ini remaja lebih cenderung memiliki kedekatan terhadap teman sebaya daripada orangtua. Remaja lebih banyak berada di luar rumah bersama dengan teman-teman sebaya sebagai kelompok, sehingga pengaruh teman sebaya terhadap sikap, pembicaraan, minat, penampilan dan perilaku lebih besar daripada pengaruh keluarga.

Penelitian yang dilakukan oleh Sujalmo (2013) bahwa tidak ada hubungan antara peran orangtua dengan kenakalan remaja. Dengan memberikan kepercayaan orangtua kepada remaja maka remaja lebih terbuka dalam pergaulan dengan lingkungan dan lebih banyak mengungkapkan apa yang remaja alami di dalam pergaulannya, sehingga kecenderungan kenakalan remaja akan lebih meningkat. Khusunya dalam penelitian ini, bahwa peran ayah tidak mempengaruhi perilaku seksual berpacaran, karena remaja cenderung lebih tertutup kepada figur seorang ayah sebagai kepala keluarga dan pemberi keputusan, yang membuat remaja menjadi lebih segan dan takut memaparkan masalah yang dialami di lingkungannya, sehingga remaja lebih cenderung melakukan kenakalan khusunya perilaku seksual berpacaran tanpa sepengetahuan orangtua khusunya ayah.

Temuan penelitian ini juga menunjukkan ada hubungan dukungan teman sebaya dengan perilaku seksual berpacaran pada remaja. Hasil penelitian ini sesuai temuan (Soetjiningsih, 2018; Maryatun 2013). Menurut Rumini dan Sundari (2004) bahwa remaja dalam kehidupan bermasyarakat dituntut untuk bersosialisasi. Remaja mulai menjalin komunikasi dengan lingkungan sekolah dan masyarakat umumnya yang terdiri atas anak-anak maupun orang dewasa dan teman sebaya pada khususnya. Pada masa ini, remaja lebih banyak menghabiskan waktu bersama dengan teman sebaya dibandingkan dengan keluarga, oleh karena itu remaja menganggap teman sebaya sebagai tokoh panutan, teman, dan kedekatan. Hal ini juga disampaikan Maryatun (2013) remaja cenderung menjadikan teman sebaya sebagai penasehat dalam berperilaku sehingga dapat menghadapi perubahan yang sama dalam membentuk hubungan dengan lawan jenis. 
Pengaruh teman sebaya dalam perilaku seksual dapat di sebabkan oleh beberapa hal. Pertama, remaja cenderung mudah terpengaruh dalam kelompok, keinginan untuk di terima oleh kelompok membuat individu termotivasi untuk mengikuti aturan yang di buat oleh kelompok termasuk melakukan perilaku seksual. Kedua, rasa ingin tahu yang besar pada remaja dapat menjadi faktor predisposisi dalam mengambil tindakan untuk berprilaku seksual. Ketiga, kedekatan dengan kelompok yang tinggi menggantikan ikatan keluarga dapat menjadi sumber afeksi, simpati, pengertia serta saling berbagi pengalaman untuk menjadi otonom dan independen. Dengan kata lain remaja memiliki kecenderungan untuk mengadopsi informasi yang di peroleh dari teman sebaya tanpa harus mendapatkan informasi yang signifikan dari sumber terpercaya (Suwarni, 2009).

Penelitian ini juga mengungkap hubungan ekspose media pornografi dengan perilaku seksual berpacaran pada remaja di sekolah swasta Yogyakarta. Temuan ini sesuai dengan penelitian yang dilakukan Soetjiningsih (2008), bahwa ekspose media pornografi mempengaruhi perilaku seksual pada remaja, yang berarti tingkat ekspose media pornografi yang dialami sebagian besar subjek penelitian tergolong tinggi. Hal ini juga disampaikan oleh Rumyeni dan Lubis (2013) dari hasil penelitiannya menyatakan bahwa perilaku remaja dipengaruhi oleh paparan pornografi di media massa.

Pada saat ini pengetahuan seksual yang di peroleh dari media masa belum bisa dijadi kan sebagai pedoman dalam perilaku seksual yang sehat dan bertanggung jawab, informasi yang disajikan cendering bersifat pornografi dan pornoaksi. Namun pada masa remaja minat terhadap seks meningkat, sehingga remaja selalu berusaha mencari lebih banyak informasi mengenai seks. Hanya sebagian remaja yang berharap bahwa informasi mengenai seks dapat dipelajari dari orangtua. Kurangnya informasi yang diperoleh dari orangtua, remaja bersusaha mencari informasi-informasi mengenai seks dari kelompok teman sebaya, internet dan berbagai media masa (Aryani, 2017).Maka dari itu sumber informasi yang baik dan bertanggung jawab diperlukan oleh remaja, agar remaja tidak salah dalam mendapatkan sumber informasi.

\section{KESIMPULAN}

Berdasarkan hasil penelitian yang telah dilakukan, maka dapat disimpulkan bahwa, ayah tidak memiliki peranan signifikan dalam melakukan pencegahan pada perilaku seksual berpacaran seorang anak. Anak cenderung lebih mendengarkan nasehat dari teman sebaya maupun terpapar media dalam berprilaku, hal ini merujuk pada penelitian ini bahwa dukungan teman sebaya dan ekspose media pornografi akan memberikan kontribusi positif maupun negative pada perilaku seksual berpacaran seorang remaja.

\section{UCAPAN TERIMA KASIH}

Keberhasilan penelitian ini banyak mendapatkan bimbingan, bantuan, dorongan, dan dukungan dari berbagai pihak, maka perkenankanlah dalam kesempatan ini peneliti menyampaikan ucapan terima kasih yang sebesar-besarnya kepada: ke dua orang tua saya (Edrizal dan Salfiati Darnis), Ibuk Dr. Nina Zulida Situmorang, M. Si, Bapak Drs. Purwadi, M.Si, Ph.D, Kepala dan para guru SMA Muhammadiyah 2 Yogyakarta, Siswa-siswa SMA Muhammadiyah 2 Yogyakarta. 


\section{DAFTAR PUSTAKA}

Aryani, I. (2017). Pemodelan kecenderungan perilaku seksual berpacaran pada remaja SMA/SMK di Kabupaten Sleman. Tesis tidak di terbitkan. Yogyakarta: Fakultas Psikologi Universitas Ahmad Dahlan.

Brooks, J. (2011). The process of parenting. Penterjemah: Rahmat Fajar. Yogyakarta: Pustaka Pelajar.

Evi., Natsir, S., \& Suriah. (2013). Perilaku seksual remaja yang berpacaran di SMA Negeri 2 Kabupaten Seram Bagian Barat. Disertasi. Makasar: Universitas Hasanuddin.

Green L. W., \& Kreuter M. W. (2006). Health promotion planning an educational and environmental approach. New York: Maylield Publishing Company.

Hurlock, E. B. (2003). Developmental psychology: A life-span approach. Terjemahan: Istiwidayanti. Jakarta: Erlangga.

Imaddudin, A. (2012). Analisis perilaku seks bebas di kalangan pelajar ditinjau dari teori $\begin{array}{lllll}\text { psikoanalisis. } & \text { Diunduh } & 25 & \text { Agustus } & 2017\end{array}$ http://counselinghouse.blogspot.com/2011/04/analisis-perilaku-seks-bebas-di.html.

Maryatun. (2013). Peran teman sebaya terhadap perilaku seksual pranikah pada remaja di SMA Muhammadiyah 3 Surakarta. Jurnal Kesehatan, 10(1), 39-45.

Pramono. J. S., Dewi. A., \& Auliatunida. Z. (2010). Pengaruh teman sebaya terhadap perilaku seksual pada remaja di SMA Negeri 8 Samarinda. Jurnal Husada Mahakam, 3(2), 4594.

Pratama. B. A., \& Setiyaningsih. R. (2015). Efek penggunaan jejaring sosial terhadap perilaku seksual pranikah pada remaja Di SMP Negeri 1 Sukoharjo. Indonesia Jurnal on Madical Science, 2(2), 2-9.

Rumyeni dan Lubis, E. V. 2013. Remaja dan pornografi : Paparan Pornografi dan Media Massa dan pengaruhnya terhadap Perilaku Siswa pada Sekolah Menengah Pertama (SMP) Negeri 25 Kota Pekan Baru. Jurnal Charta Humanika. Vol. 1 No. 1

Rumini, S., \& Sundari, S. (2004). Perkembangan anak dan remaja. Jakarta: PT. Rineka Cipta. Santrock, J. W. (2003). Adolescence: Perkembangan remaja. Terjemahan: Shinto B. Adelah dan Sherly Saragih. Jakarta: Erlangga.

Santrock, J. W. (2011). Life- span development. perkembangan masa hidup. Penterjemah: Benedictine Widyasinta. Jakarta: Erlangga.

Soetjiningsih, C. H. (2008). Faktor-faktor yang mempengaruhi perilaku seksual pranikah pada remaja. Disertasi. Yogyakarta: Universitas Gajah Mada.

Sujalmo, P. (2013). Hubungan peran orangtua terhadap kenakalan remaja di SMP 2 Mlati Sleman. Skipsi[tidak diterbitkan]. Yogyakarta: Universitas Gajah Mada.

Suwarni, L. (2009). Monitoring parental dan perilaku teman sebaya terhadap perilaku seksual remaja SMA di Kota Pontianak. Jurnal Promosi Kesehatan Indonesia, 4(2), 127-133.

Taufik, A. (2013). Persepsi remaja terhadap perilaku seksual pranikah (studi kasus SMK Negeri 5 Samarinda). Ejurnal Sosiatri-Sosiologi. 1(1), 31-44.

Utari., Syarifah., \& Lubis. N. L. (2012). Hubungan media elektronik dengan perilaku siswa tentang seks pra-nikah di SMK Muhammadiyah 2 Kota Pemantangsiantar. Disertasi. Sumatera Utara: Universitas Sumatera Utara.

Yeung, \& Jean, J. W. (2015). Asian fatherhood. Journal of Family Issues. 34(2), 143-160. 